\title{
ELEMENTS OF MOLOKAN CULTURE IN THE KARS REGION WITHIN THE CONTEXT OF CULTURAL GEOGRAPHY AND CULTURAL TOURISM
}

\author{
Şaban ÇELİKOĞLU* \\ Zonguldak Bülent Ecevit University, Ereğli Faculty of Education, Department of Turkish and \\ Social Sciences Education, Kdz. Eregli, Zonguldak, Turkey, e-mail: sabancelikoglu@beun.edu.tr
}

\section{Evren ATIŞ}

Kastamonu University, Faculty of Arts and Sciences, Department of Geography, Kastamonu, Turkey, e-mail: evrencografya@gmail.com

\begin{abstract}
Citation: Çelikoğlu Ş. \& Atış E. (2020). ELEMENTS OF MOLOKAN CULTURE IN THE KARS REGION WITHIN THE CONTEXT OF CULTURAL GEOGRAPHY AND CULTURAL TOURISM. GeoJournal of Tourism and Geosites, 29(2), 597-613. https://doi.org/10.30892/gtg.29217-492
\end{abstract}

\begin{abstract}
In the present study, traces of the Molokan culture in the Kars region have been discussed in term of human-locality interaction. In this context; what the reasons that forced the Molokan to migrate from Russia to Kars were, what kind of cultural traces they left during their stay in the region, and which communities they interacted with in the region were all examine. Furthermore, it was aimed to produce answers to the questions such as what the cultural elements starting with the Molokans in the region and surviving in the present day were, how the existing Molokan cultural elements could be evaluated in the context of cultural tourism. For this purpose, the villages of Çakmak, Boğatepe, İncesu, Porsuklu and Yalınçayır where the Molokans lived densely, were selected as a sample and observation trips were organized to these villages. The interview method was used in order to obtain the information and opinions of the local people. As a result of the studies carried out, it was understood that the architectural elements such as houses, dairy farms, stables, mills, bridges and cut stone paved roads survived in the region from the Molokan to the present day, and they led the local people in many professions, especially cheese making and milling.
\end{abstract}

Key words: Kars, Molokans, Migration, Culture, Cultural Tourism

\section{INTRODUCTION}

Culture is one of the important means in shaping the geographical appearance. While culture, which is a way in which groups of people can adapt themselves to the environment through collective behavior and technology (Sutton \& Anderson, 2014: 14), allows people to adapt to their environment, on the one hand, it enables the environment

\footnotetext{
"Corresponding author
}

http://gtg.webhost.uoradea.ro/ 
to be adapted to the human's own needs, needs and goals, on the other hand (Cuche, 2013: 9-10). According to their characteristics of cultural development, people can create a social order on the one hand, and develop civilizations with different levels of development within the physical environments on which they live.

The different cultural elements generated by the societies form the cultural landscape of the place they live on together; in other words, its cultural geographical appearance. Cultural groups can change their locations over time for natural, human or economic reasons and transfer their cultural accumulation to their new locations.

This situation is both related to habits and accumulations and it is a manifestation of the desire to create and maintain the old in the new locality. The ethnic or religious groups participating in the migration movement and make sure that they live and maintain their culture in their new locations. They embrace their culture as the only element that holds their communities together. They are anxious about being assimilated or melt away within the new cultural pots. However, they interact with different cultural groups where they migrate and acquire new cultural elements.

Geographical spaces provide a basis for the development of human communities and different geographical environments determine the formation of different nations and cultures. In a nut shell, geographical diversity is the precursor of ethnic and cultural diversity (Atasoy, 2019: 80). As Lev Gumilev stated: "The reason why Homo Sapiens species exists in the natural environment is the ethnos, and the differences between ethnos are not determined by language, religion, education or races, but are determined by the attitudes and behaviors of people. We should not forget that the most powerful factor determining these attitudes and behaviors is the way people accommodate themselves and adapt to the geographical environment" (Slaveykov, 2006: 15). In other words, ethnos or ethnic communities are an integral part of geographic space; they are both influenced by it and influence it. Ethnos emerge in certain geographical spaces, shaped by ecosystems and their natural elements; they evolve, spread here, and sometimes disappear here as well when they are due. Geographic space is inevitable for ethnic communities; it is because the place of birth, growth and development, and the place of death of the ethnos are their geographic space, which is their destiny. In summary, ethnic identities emerge, develop or spread in certain geographical spaces under the influence of certain conditions, in which this complex and multidimensional process is called "ethnogenesis" (Somersan, 2008: 76). At the stage of ethnogenesis, while the ethnic communities are influenced by the socio-cultural characteristics of neighboring states, cultures and societies, they have an impact over them to a certain extent well as. Geographical space is the place where ethnic communities both influence and are influenced thanks to their human, economic and natural features; it is also the beginning and end of ethnogenesis; it is its place of birth as well as death (Atasoy, 2019: 80).

The Molokans of Kars Region, which is the subject of this study, is a community which has been subjected to migration at certain intervals and has been detached from its cultural places. Nevertheless, Molokans managed to preserve their cultural values and were able to shape their new spaces in line with their culture.

According to scientific sources in Russia, the founder of the Molokan movement is Semen Uklein (Rusian7, 2017). In the late 17th century, Dukhobor and Molokan (or Spiritual Christian) denominations emerged in Russia. These groups were the free peasants whose social base was based on the ideas of Western Protestantism. It was because their teachings contained ideas that undermined the secular authority. Including the defense of the homeland, they faced difficulties both in the Tsarist and Soviet times because they rejected violence (Inikova, 2007: 78). 
There are three theories put forward by the Russian scientists about the origin of the name Molokan: According to the first theory, the Molokans drank only milk on the days of fasting because the Christian Orthodox laws prohibited the food intake. Moloko means milk in Russian. That is the reason why they were called Molokan, which means 'drinking milk'. According to the second theory, the Molokans were named after the Molochna (Молочной) stream in the Melitopolsk district, where they were exiled from the northern coast of the Azov Sea. According to the third theory, the Molokans chose to refer to the "spiritual milk "metaphor of the Holy Bible, they called themselves by the same of this community (Baptistru, 2020). The religious dissidents, called Spiritual Christians or Russian Serkans, gathered from steppe areas during the reign of Tsar Alexander I from 1801 and settled on the plains around Sütlü Creek (река Молочна) in the north of the Azov Sea; they were, then, deported to the Caucasus with an ultimatum given by Nikolai (Akçayöz, 2015: 27). The Molokans who were forced to leave the Moloçna region were told that they had no place in any territory within the borders Russian Empire except the Caucasus, it has been reported to be located, the Molokans and Starovers took to the roads looking for new locations for immigration and established villages on the borders of Armenia, Georgia and Turkey (Denisenko, 2009: 62).

Molokans who were settled around Azerbaijan, Georgia, and Armenia in the Caucasus between 1830-1839 in order to establish Russian settlements on the new border line of Russia remained neutral during the Ottoman-Russian War of 1877-1878 and established very good relations with indigenous peoples. After the war, they were settled in the Kars and Erzurum regions where the Russian settlements in the Caucasus were located (Denisenko, 2009: 62). As it is commonly known, Kars and its surroundings were given as compensation to the Russian Empire at the Berlin Conference which was convened as a result of the 1877-1878 Ottoman-Russian War (the '93 War). Thus, for more than 40 years, Kars and its surroundings remained under the Russian rule. During this period, various ethnic and religious communities were displaced, forced to immigrate and settled in line with the settlement policy of the Russians. Starting from the end of the XIX century till the beginning of the XX century, the Russian population in the Kars region reached about 11000 people. About 6500 of this population consisted of Molokans and about 3000 Dukhobors (Semyenov \& Karagöz, 2009: 112).

Since the Molokans considered murdering someone as a great sin, they refused to fight and go into the military service; for this they were sentenced to years of imprisonment and exile and were persecuted. As a result of their pacifist, peaceful beliefs against the war, the Molokans resisted the mandatory arming of Tsar Alexandr III in 1887-1889, and instead of succumbing to the pressure of the Tsar government, they began to emigrate extensively in 1904-1911from the Russia, especially to the Americas. The Molokans, who settled in the United States at the end of their permanent migrations, continued their peaceful attitudes and they did not participate in $1^{\text {st }}$ and $2^{\text {nd }}$ World Wars (Denisenko, 2009: 60). The Molokans in the Caucasus region immigrated to the USA (California), Canada, Mexico and Australia. It is stated that the famous Russian writer Lev Tolsloy donated the income of his novel "Resurrection" to the migrating Molokans and sent letters to the countries to which they were going to (Arat, 2019: 209).

As a result of the Ottoman Russian War of 1877-1878 (the '93 War), Kars and its surroundings, which were under the Russian rule, were reclaimed in 1920 and the borders were drawn with the 1921 Moscow and Kars Agreements. While a significant part of the Molokans returned to Russia, some stayed and continued to live in peace in Turkey (Arat, 2019: 209). Finally, in 1962, the Molokans immigrated to the city of Saratov, which was founded by the Volga River in Russia (Figure 1). It is commonly known that the 
political and social developments that took place during the USSR era caused psychological and social unrest among the Molokan community. Moreover, in the Molokan belief system, since it was a sexual taboo to marry even with someone from 5-6 generations earlier, the fact that they did not want to have to marry with very close relatives and that they did not marry with indigenous people caused this migration (Türkdogan, 2005: 7). In the interviews conducted in the region, it was emphasized that the Molokan girls married with the local people and continued to settle here, but the Molokan boys had almost no marriages except their own people.

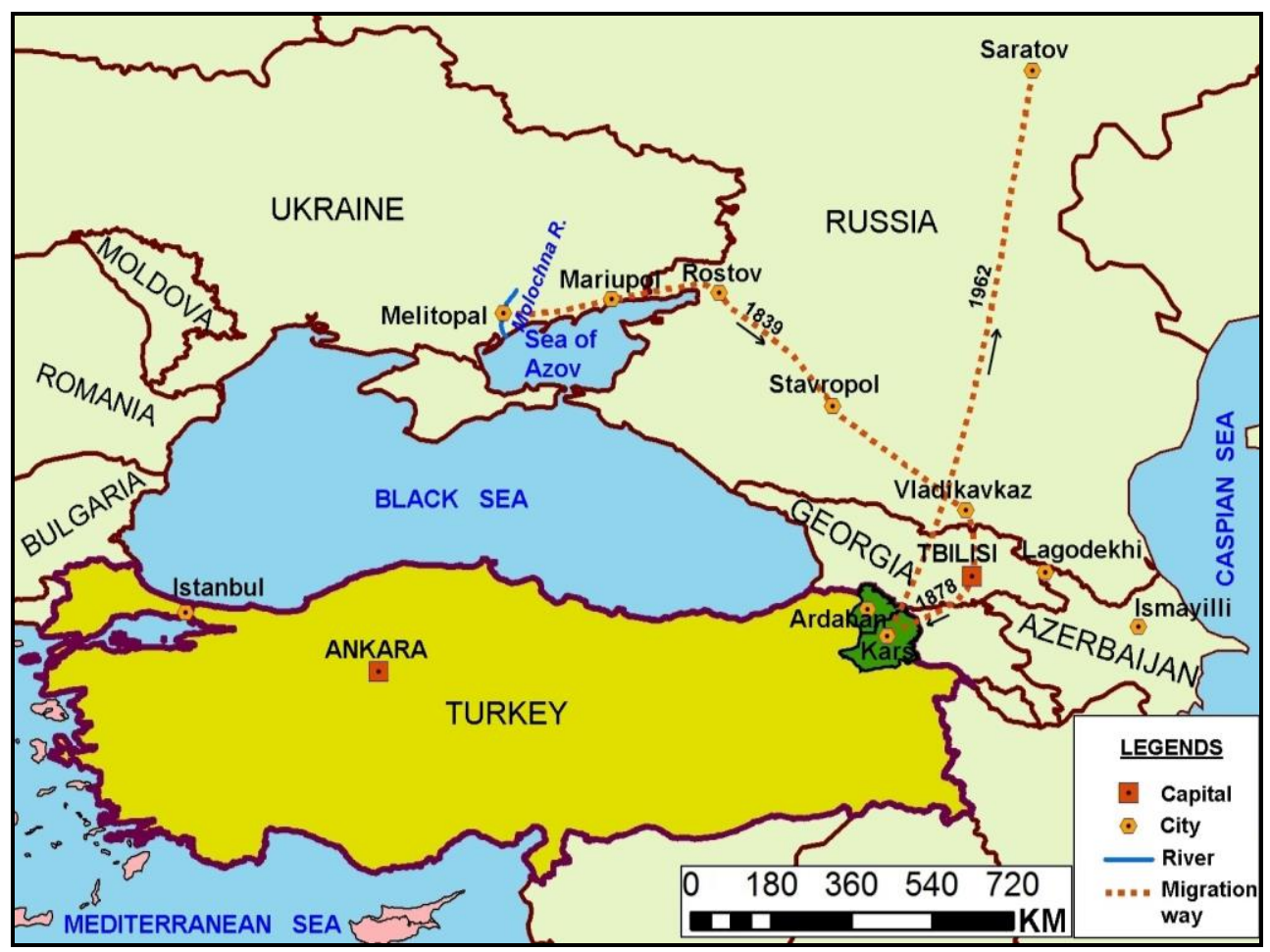

Figure 1. Migration map of the Molokan communities

(Source: It was drawn from google map with ArcMap 10.2)

The Molokans who left Turkey for Russia, they maintained their folklore, economic activities and cultural traditions during the period they lived in the Kars region; they contributed to the local culture in many areas, especially in cheese making and milling.

\section{OBJECTIVE AND METHODS}

The Molokan families, who had lived in the Kars region for almost 80 years, maintained their cultural accumulation with them during this period; they shared many cultural characteristics, especially cheese making and milling, with the local people, interacted with them and made certain social, economic and cultural contributions to the shaping of the cultural landscape.

Up to the present time, various studies have been conducted on the religious, ethnic and social structures of Molokans. However, it was observed that the studies focusing on the subjects such as human-locality interaction and the organization of the 
locality, which constituted the focal point of the geographical studies, have not been included. The aim of this study is to identify the economic, socio-demographic and cultural traces of the Molokan community in the Kars region, and examine all of these in the context of cultural tourism and introduce their possible contributions to the local tourism. In this context, answers to the following questions were sought;

$>$ What are the reasons that have forced Molokan communities to migrate from Russia to Kars region?

Which architectural, economic and socio-cultural traces (ruins) have the Molokan communities left during their stay in the Kars region?

$>$ After the 1877-1878 Ottoman-Russian War (the '93 War), were there any other nations that immigrated to the Kars region?

$>$ Which communities did the Molokan communities interact with in the Kars region and what is their evidence?

$>$ What are the socio-cultural elements that have started with the Molokans in the Kars region and survived today?

$>$ How can the Molokan cultural elements in the Kars region be utilized in the context of cultural tourism?

> What initiatives can be taken to get the Molokan communities living in various countries and regions of the world to visit the Kars region on certain dates each year and contribute to the region by spending foreign currency in the region?

Furthermore, during the field studies, the problems faced by cultural values were noted down, and it was aimed to make suggestions about what could be done for the protection and sustainability of these cultural values, which really make a difference and provide richness for the region.Qualitative research methods were used for the study.

Firstly, documentary data related to the subject were searched and secondary data related to the study were compiled. In order to establish the conceptual framework of the study, theses in YOOK Thesis Center were searched thematically, and all the academic and scientific publications about the Kars region and Molokans were collected and examined. After that, the primary data that would form the framework of the study was started. For this purpose, observation trips were organized to these villages and observation notes were taken, photographs were taken and interview method was used to obtain information and opinions of the local people. Semi-structured interview forms were used in the face-to-face interviews. The interviewees were identified by snowball sampling.

\section{SETTLEMENT OF THE MOLOKAN COMMUNITIES IN THE KARS REGION AND THEIR REPERCUSSION ON THE ECONOMIC LIFE}

As a result of the Ottoman-Russian War of 1877-1878, the Kars region was acceded to the rule of the Russian Empire. Kars, which was a district of the Erzurum Province during the Ottoman period, expanded its borders as far as the Ardahan and Oltu Townships when it was transferred to the Tsarist Russia and was incorporated as an Oblast into the General Governor of Zakafkasya (Ortayll, 1978: 344). During this period, Kars region witnessed intense Slavic migration in accordance with the settlement policy of the Russians. Families of Slavic origin settled mostly in Kars, Zaruşat (Arpaçay), Şuragel (Akyaka), Cilavuz (Susuz), Novo Selim (Selim) and Ardahan townships. As of 1888, there was a Slavic population of 10671in 1426 households in 22 villages. Among these, Molokans constituted the most populous group with a total of 6612 people in 937 households in 12 villages (Table 1 ). At the end of the $19^{\text {th }}$ century, in addition to the people of Slavic origin, there were also people of other communities such as Germans, Swiss, Greeks, Assyrians, Armenians and Yezidis who settled in Kars. The Molokans managed to 
live in peace with these ethnic groups and the Turks, interacted with them culturally and made significant contributions to the cultural and economic development of the region.

Table 1. Population of Slavic origin living in the Kars Province in 1888

(Data Source: Badem, 2010: 88)

\begin{tabular}{|l|c|c|c|}
\hline \multicolumn{1}{|c|}{ Group } & Number of Villages & Number of Households & Population \\
\hline Orthodox Russian & 4 & 179 & 1.086 \\
\hline Duhobor & 6 & 310 & 2.973 \\
\hline Molokan & 12 & 937 & 6612 \\
\hline Total & 22 & 1426 & 10671 \\
\hline
\end{tabular}

Since the Molokans settled in the region of Kars generally chose the rural areas instead of city life and possessed developed agricultural culture, they preferred the fertile land areas and waterfronts where they could do milling; they established new villages such as Sulakyurt (Nikolayevka), Şahnalar, Karahan, Çakmak (Blagodarnoe) and İncesu (Malaya Voront-sovka). In addition to this, they lived in the villages of Meydancık, Yalınçayır (Zührap), Yolboyu (Romanovo), Eşmeyazı, Boğazköy (Prohladnoye), Yolaçan (Aleksandrovka), Kümbetli (Vladikars), Planting (Novo Mihailovka), Çamçavuş (Vorontsovka), Karakale and Boğatepe (Zavod) (Figure 2).

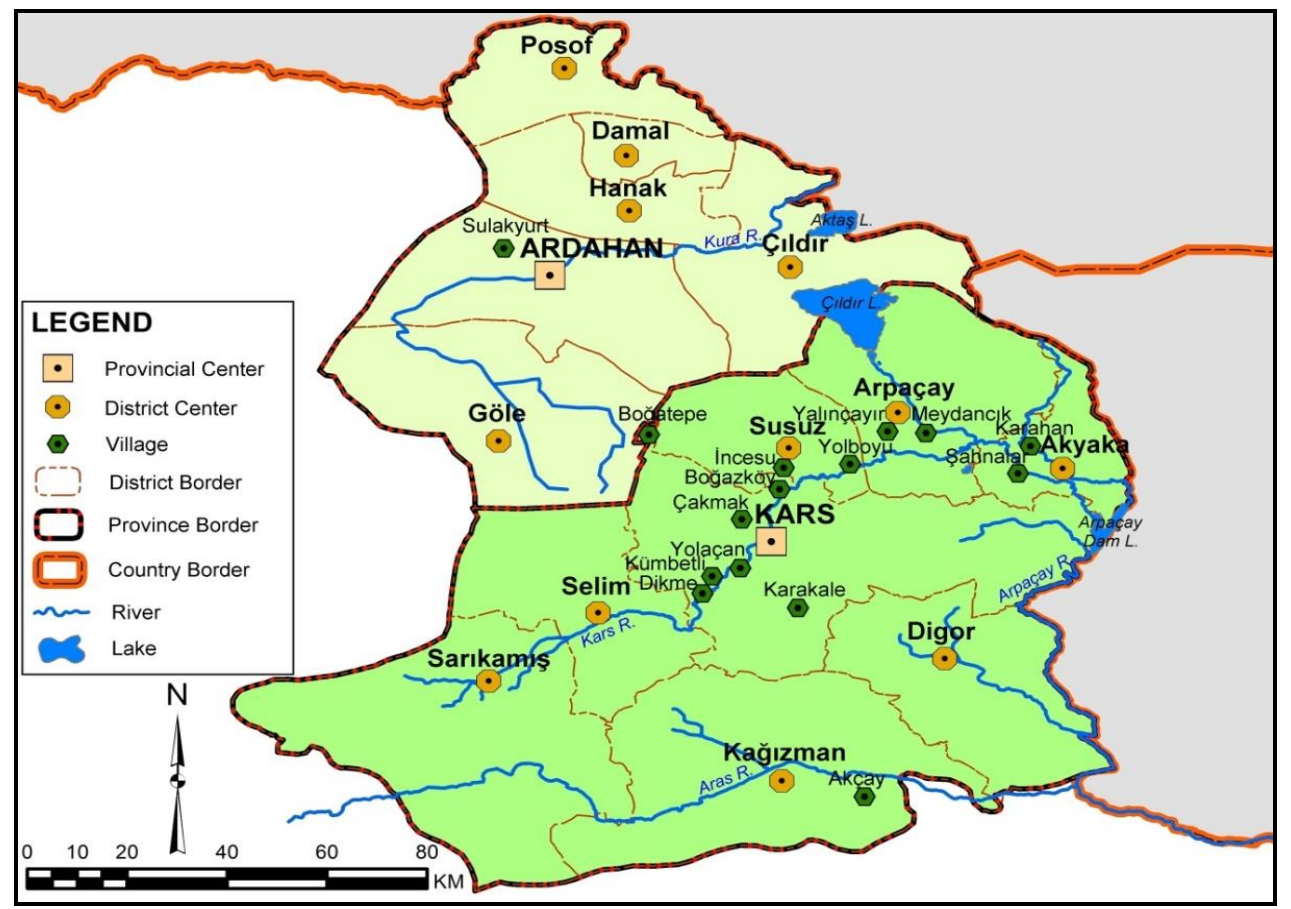

Figure 2. Main Villages where the Molokan Communities Lived in the Kars Region (Source: It was drawn from google map with ArcMap 10.2)

The village of Boğatepe, which is located in the central district of Kars, was allocated to the Molokans as a plateau as it was located on a plateau flat of $2200 \mathrm{~m}$ altitude, approximately $5 \mathrm{~km}$ west of Büyükboğa Tepe $(2732 \mathrm{~m})$. The village of Boğatepe is one of the most recently established and developed settlements. On a trip to the region he 
made, a Swiss citizen named David Moser found that milk was produced and that the milk was of suitable quality for cheese production. Boğatepe made significant progress with the establishment of four "Zavods", which means a factory in Russian (Atış \& Çelikoğlu, 2018: 315). The endogamic community structure of the Molokans because of their beliefs made them a homogeneous society in terms of ethno-cultural characteristics that were resistant to external religious and social influences and changes (Figure 3).

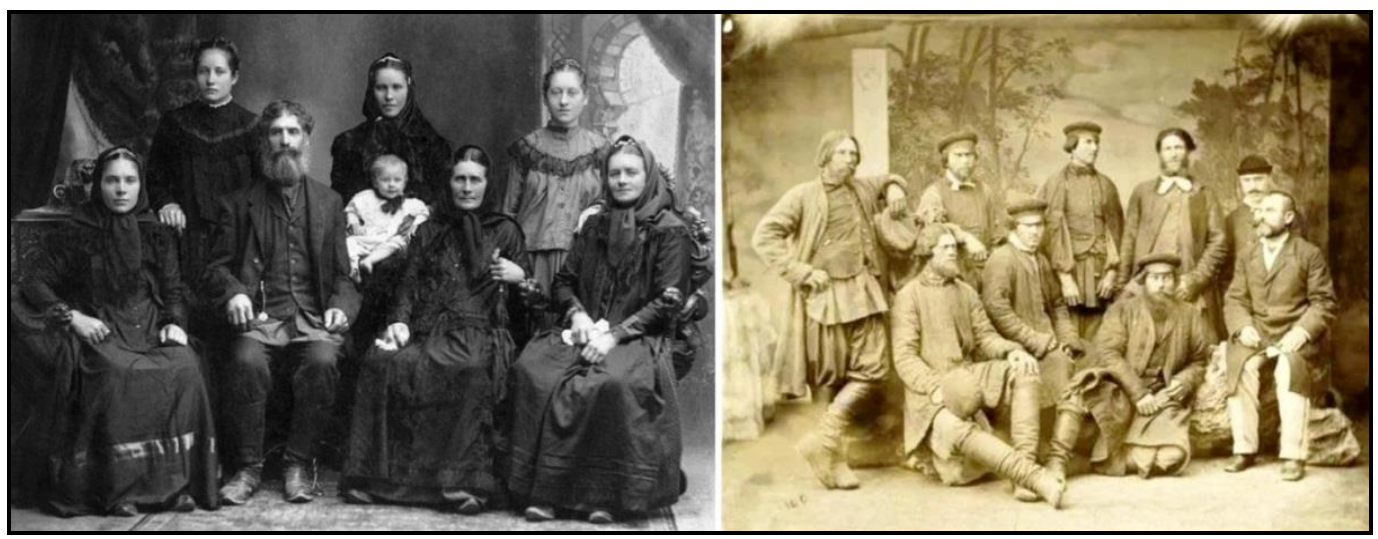

Figure 3. Molocan family with traditional clothes (Source: Rusian7, 2017), Molokan men in 1970's

(Source: Molokans Wordpress, 2012)

However, contrary to these conservative features in their socio-cultural structures, the Molokans, which were open to innovations in technological field, were the most important driving force of the region in the modernization process in agriculture and animal husbandry (Suvari, 2013: 70). Under the rule of the Russian Empire, there were significant developments in animal husbandry and agricultural technology in the Kars region. In agriculture, horse and heavy plow were widely used; as a result, from 1884 to 1913 arable land increased 2 times, agricultural population 4 times. The horses used here were an interesting hybrid breed of big horses, what the local called "the Molokan Horse". Until the Second World War, the horse was regarded as a «combat vehicle» in Turkey, strong and muscular breeds to be used in agriculture were bred. Kars was an exception in this regard during the occupation period. The Molokan horse, a big horse breed of Kars origin, carried the blood of the cold blooded big horse breeds of Europe such as Ardene, Percheron, Breton and Clydestale and Beljik. The breed, which emerged after mixing with Orlof and Bituyik breeds in Russia, was hybridized with the native breeds of Kars and 1.48-1.58 tall pack horse called Molokan horse emerged. However, this breed has been degenerated due to lack of good breeding in Kars (Ortayll, 1978: 355).

Dairy breeding and dairy farming developed in Kars during this period, and a hybrid cattle breed called Zavod cow or Molokan cow became a common species. This cow is probably a cross breed called Siementhal species where one of the native breeds was hybridized with Danish red (Ortayli, 1978: 355). During the Molokans period, beekeeping, cattle breeding and soap production became widespread in Kars and its surroundings. Beekeeping, which is still an important source of income in the Kars region, became widespread thanks to the innovations in the hive and honeycomb methods introduced by the Molokan families. Moreover, the honey produced in the Kars region is among the highest quality honey in the world. The Molokans benefited from mechanical energy as well as the organic energy in the region. The Molokans who achieved great success in soap 
manufacturing established their own repair shops and these shops still exist today (Akça \& Kıyanç, 2017: 38). Since the Molokans were humble and hardworking, they established new villages wherever they settled down in the Caucasus; they planted products that had never been planted previously in the regions by harvesting products; they sold their harvest by using their food, the railways, and all kinds of transport and earned their living. They were quick to build a mill on many rivers in this mountainous region. By the end of the century, they generally became financially self-sufficient. Among the Molokan families, there were also those who became rich thanks to milling and agricultural trade and eventually rode very high (Denisenko, 2009: 62-63).

\section{MOLOKAN CULTURAL ELEMENTS IN THE KARS REGION}

During their stay in the Kars region, the Molokans left their cultural traces in such fields as architectural styles, dairy and stables, mills, roads, bridges and cemeteries, as well as soap making, beekeeping and cheese making, and applied their own traditional cultural experiences in some local activities. These people who were settled in the villages of Kars and its vicinity contributed significantly to the local culture. In their villages, which they planned with a new town planning approach, they tended to build houses in a sequential order on both sides of a wide and long-held main street. They paved their streets and avenues with stone. The entrances of the dwellings faced the avenues and the walkway was paved with stone and the edges were designed as a flower garden.

After the Molokans migrated to the Kars region, they established many villages in the region or settled down in villages vacated by the Muslims. These villages had a unique architecture. These villages, built on wide plains and wetlands, consisted of houses on both sides of the road. Wide spaces were left on both sides of the road. The houses consisted of thick walls and a roof. The opening of the doors to the south and the high windows were important measures taken to keep pace with the seasonal conditions.

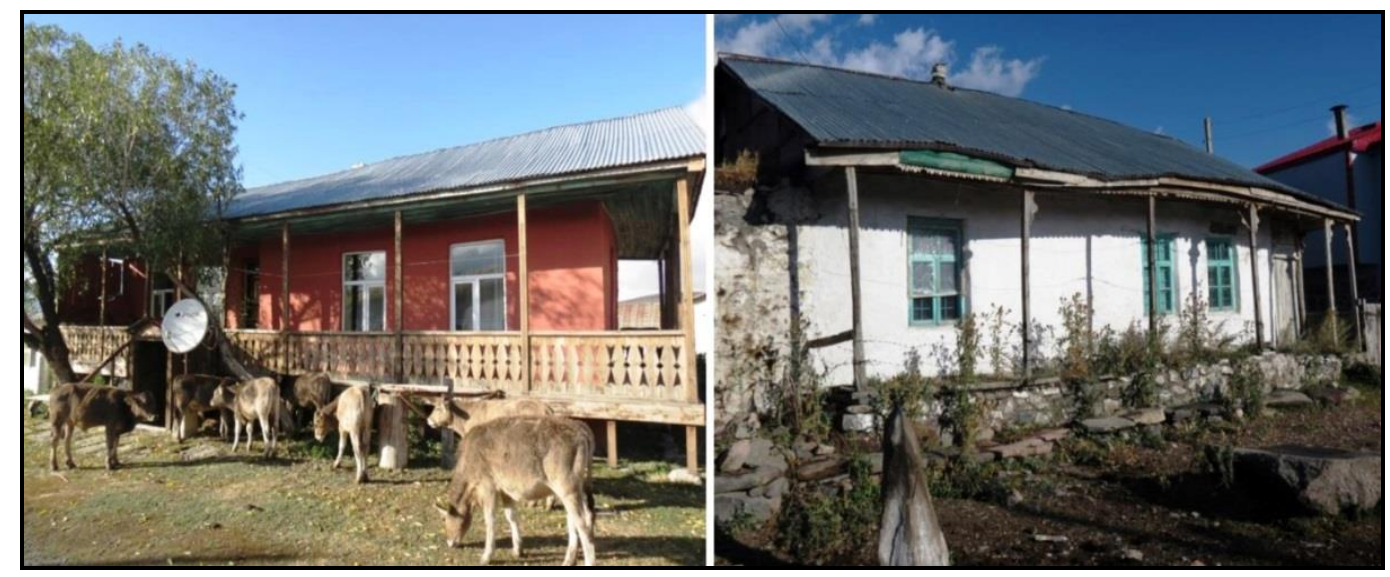

Figure 4. An example for the single-storey houses of Molokans with cradle roofs and verandas from the village of Boğatepe located in the Kars region

While the ceiling heights of the houses provided better temperature preservation, the stoves called with wall heating feature 'peç' were used. In the gardens of the houses, there was a separate part called "Orchard" where fruits and vegetables suitable for the climate as well as flower species were grown. Additionally, there were fields called "Napızar" which were suitable for the regional structure. Between each of the seven 
houses there were roads called "Gaps". These roads were used to reach the fields as well as the passage of small and large cattle. This architectural order and settlement structure in the Molokan villages has largely been destroyed today. In the study conducted in the region, villages such as İncesu, Çamçavuş, Meliköy, Çakmak and Yolboyu in the Susuz district of Kars are among the best examples of the Molokan village structure. It was established that there were large architectural differences between the villages established later in the region (Akça \& Kıyanç, 2017: 35-36). The application of wooden pole patio in front of the houses in the Kars region was introduced for the first time by the Molokans. It was observed in later years that the local people adopted this architectural style in their houses as well. It is clearly seen that the people of Molokan attached importance to fine carving technique ornaments on the wooden door and window shutters. Furthermore, the Molokans spread the use of cradle roofs reinforced with wooden beams instead of flat roofs in Kars and its surroundings (Özkan, 2015: 11) (Figure 4).

Even though the Molokan houses are mostly single storey, there are also examples of two-storey houses. In the two-storey examples, it is observed that the entrance of the guest room was separated from the family space for the purpose of hosting guests well and protecting the family privacy (Figure 5). The Molokan houses have basement floors called "badval". Perishable products such as meat, fresh vegetables, green vegetables and fresh fruits are stored here. The roof sections of the houses have sections called "grişga". They serve as storage for the durable household items.

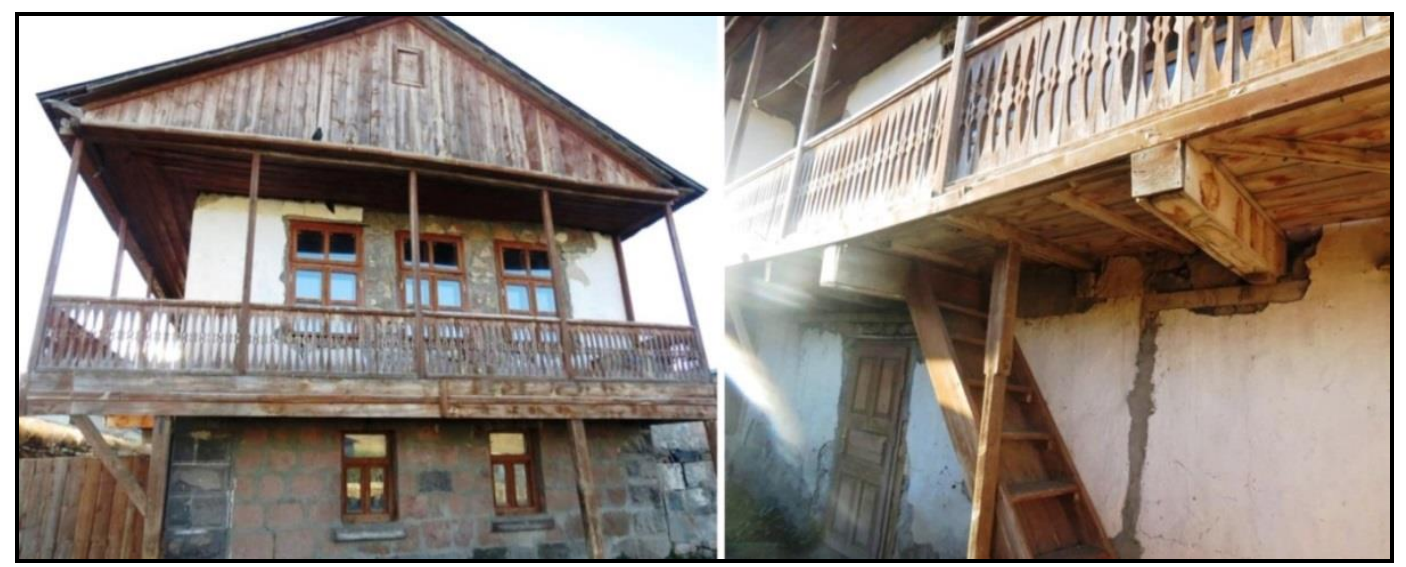

Figure 5. An example of two-storey Molokan house in the Kars region

On the south-facing façade of the Molokan houses, there is a veranda section with wooden steps built with masonry rubble stone, which can be reached with several steps. The use of a veranda on the front façade is a characteristic of the Molokan village houses This architectural element was gradually adopted by the local Turkish people and became widespread around Kars and Ardahan provinces (Özkan, 2015: 11).

In the Molokan houses in the Kars region, it is clearly seen that stone and wood materials were used to a certain extent. It is possible to say that the natural environmental characteristics of the region have also contributed to this. The widespread distribution of volcanic lands in the region has enabled the use of basalt rocks in the building structures. The stone material was mainly used as masonry material for raising houses from 60 to $80 \mathrm{~cm}$ above the ground floor. In this way, it was aimed to extend the life of the building both by placing the house on a solid ground and by reducing the 
moisture effect. In some houses, it is seen that the verandas are open underneath and they are placed on basalt stones in order to prevent the wooden porch from decaying by breaking the contact of the wooden veranda with the soil. One of the areas where stone material is used in the Molokan houses is the walls. It is clearly observed that masonry was mostly applied on the walls of the houses.

The fact that the Kars Region is close to Göle and Sarıkamış forests has enabled the use of wood materials. In this way, elements such as verandas, ceilings and roofs, doors and windows, shutters, floor divisions and interior stairways stand out as the main areas where wood has been used. Some houses have a horizontal rectangular window on the door in order to illuminate the interior. Windows on the façades are generally rectangular in shape and have double sashes. Some houses also have window shutters.

The wooden components of the houses are decorated with examples of Molokan culture. This application is most commonly observed in windows and doors and balcony railings. In the ornaments, symmetrically processed geometric shapes have been used instead of religious figures as a manifestation of their beliefs (Figure 6).

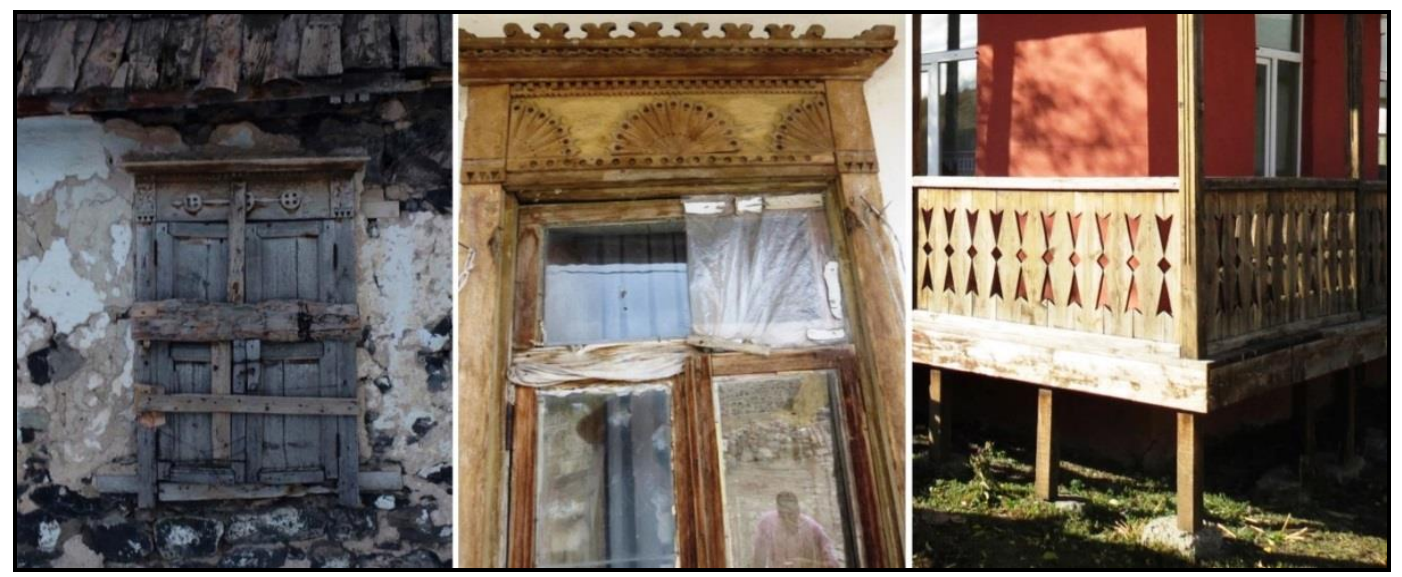

Figure 6. Examples of Molokan culture decoration in the wooden components of the houses (the Kars region)

The Christian Molokans were opposed to worshiping in majestic churches. They thought that for the places of worship which they called "sobranie", it was sufficient for these worshiping structures to have one section, be unpretentious and possess limited amount of furniture. As a matter of fact, the Molokan-made "sobranie" building located in the Eşmeyazı Village, which is currently used as a school building, does not at all bear the appearance of a church. The cultural features of the Molokans, such as the fact that they did not include the symbol of the crucifix in their places of worship, their lives and graves, that they were peaceful and sharing people, and that they did not eat pork, were effective in their acceptance by the Muslim people in the region. The Molokans are a community experienced in water milling. In this context, one of the important structures in the villages is the mills, which were used by the Turks in the region in the following years (Figure 7). In some villages, it was mentioned that the local people talked about the Molokan millers who continued the flour milling work during the Republican Period. In the interviews, it was stated that there were public baths resembling houses based on common use among the Molokan structures in the local villages. However, it was also stated that such structures were either demolished or transformed into another area of use. 
It was observed that some possessions from the Molokans are still used today in the Kars region. One of these is the wooden cabinets, which Molokans call the "isgap", taking on the task of today's showcase cabinets. The word "İşgap" or "işgaf" also appears as a cabinet in the Turkish Language Association's compilation dictionary. The "işgaps" are functionally covered cabinets in which dry food and various items are kept. While there are drawers in the middle of the cabinets, the upper compartments consist of shelves with glass doors. It is observed that carved and relief samples are frequently used on the cover and drawers. The manifestation of the inner world and accumulation of the people of Molokan are the Molokan carpets which are among the elements that reflect cultural richness. In the Molokan carpets, one can clearly observe the symmetrical use and preference of geometric shapes, floral patterns and vivid color (Figure 8).

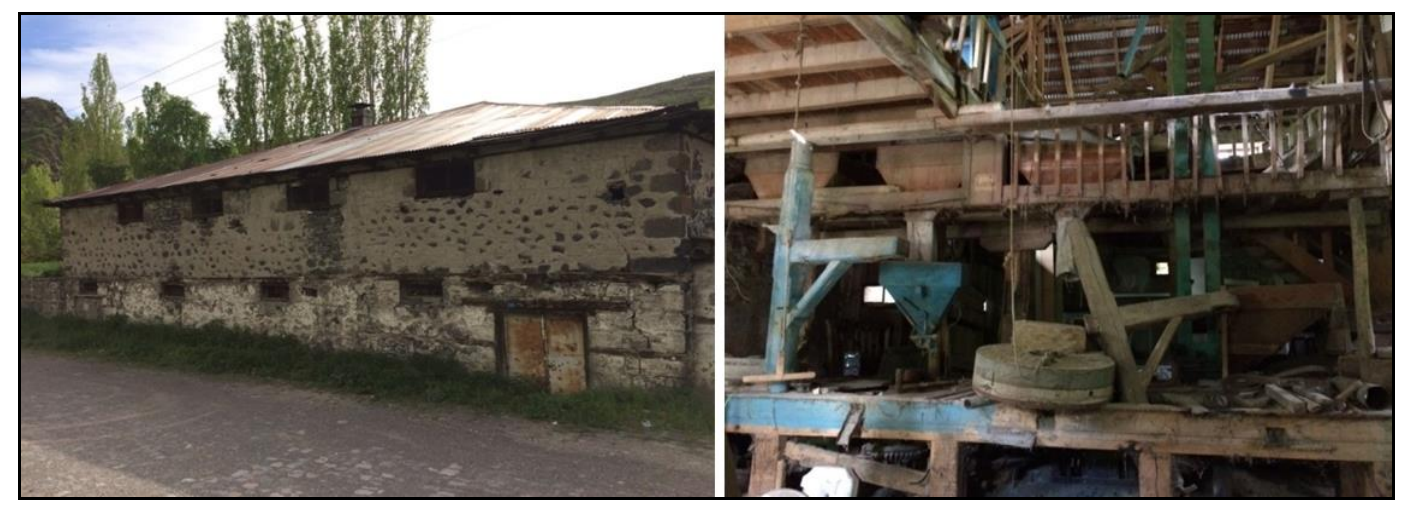

Figure 7. An old mill from the Molokans on the Kars Stream

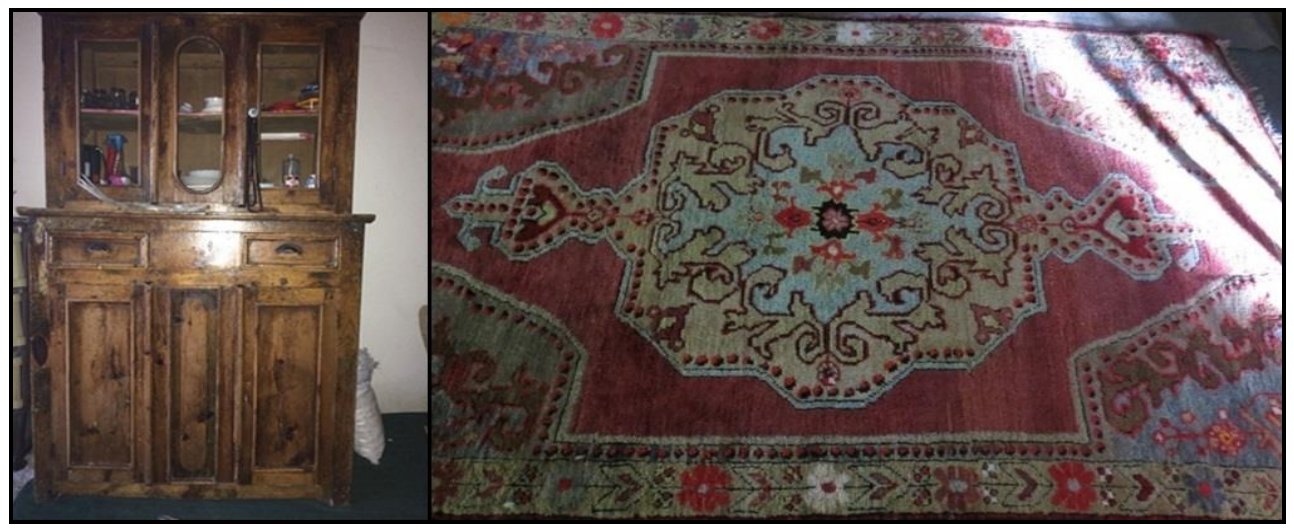

Figure 8. Molokan-Made İşgap (Cabinet) in the Çakmak Village in the Kars region and an example of a Molokan carpet from the Boğatepe village

Stables and dairies in the Kars region that have survived from the Molokan to the present day are important. It is clearly observed that these buildings were covered with $40-50 \mathrm{~cm}$ of soil in accordance with the climate of the region and grasses grew on them. In this way, stables and dairy farms were kept isolated against extreme cold in winter. The stables were usually built with high ceilings and a large structure. In this way, an airy environment for animals was created indoors. Wooden beams on the ceilings of the stables and thin beams of basalt were used to cut the bonding of the planks laid at half- 
meter intervals to the soil and prevent rain leakage (Figure 9). The roof structure in question makes the stable cool in summer and warm in winter. Due to the favorable weather conditions indoors, some dairies today are used as rest rooms for Kars kashar and Gruyere cheese. In fact, it is emphasized that the cheeses rested in these structures turn out to be more mouth-pleasing than those rested in the new reinforced concrete structures. The basalt plateaus in the Erzurum-Kars-Ardahan region are among the Turkey's busiest cattle breeding zones; the fact that there is sufficient rainfall in summer in this region has generated economic consequences such as the fact that the extensive alpine meadows remain green throughout the summer and high grass yield (Doğanay, 2011: 201). The province of Kars located on the Erzurum-Kars plateau has been an important livestock center and livestock market since ancient times thanks to its rich grass presence and promoted itself with dairy products (Koday, 2005: 180).

In the Kars region, under the rule of the Russian Empire, a hybrid cow type called "zavod cow" or "the Molokan cow" generated an increase in meat and milk yield in livestock (Yurt Encyclopedia, 1982: 4497). This cow breed was named "zavod", which means the factory in Russian because of its high milk yield. This term also refers to dairy farms in Turkish. As a matter of fact, gruyeres and kashar cheeses and dairies producing butter, namely "zavods", became widespread in Kars in the period in question.

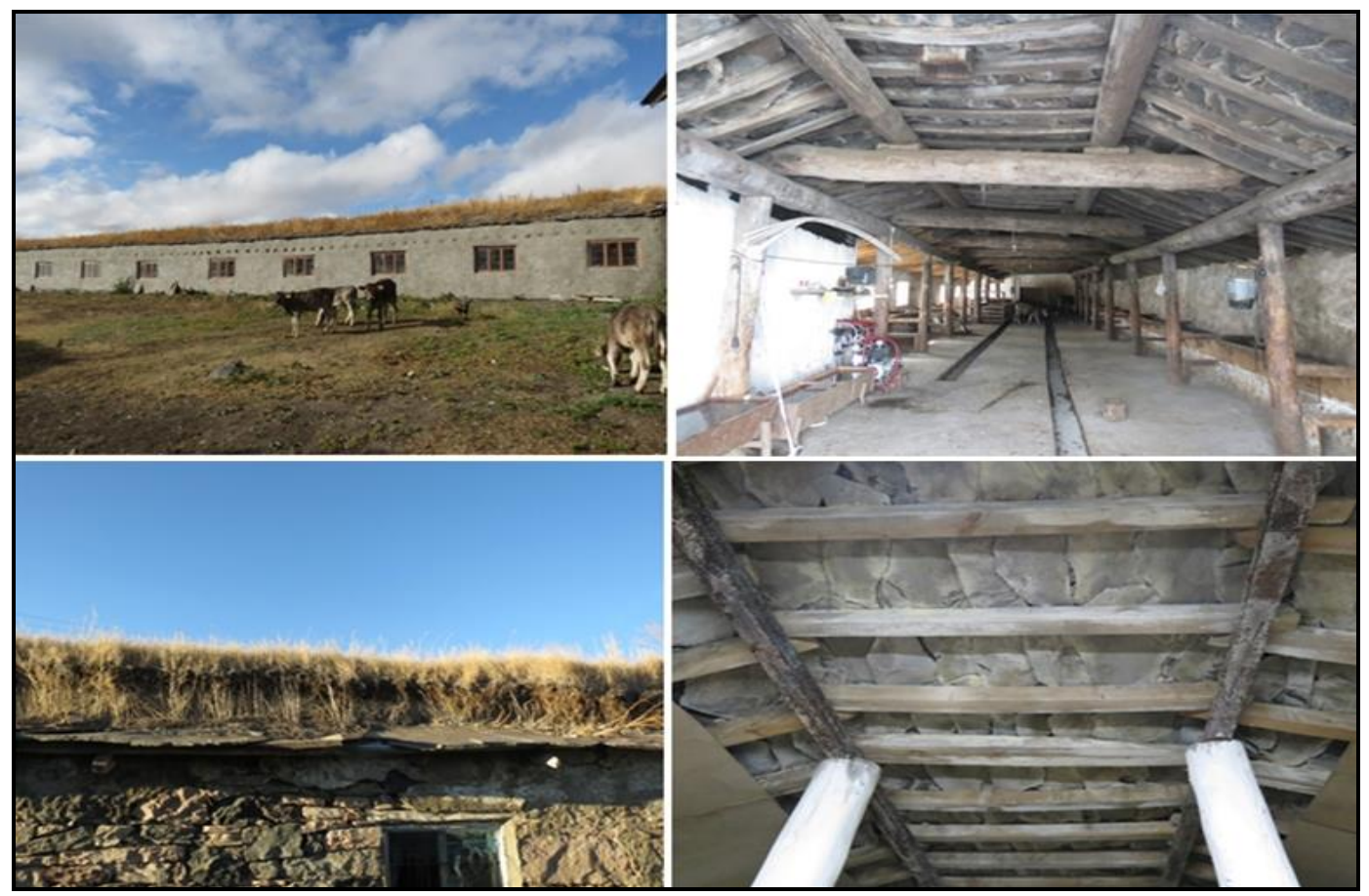

Figure 9. Views of the stables and dairies surviving from the Molokans to the present day

The Molokan (Zavod) cattle have an important role in the development of cheese production in the Kars region. Molokan immigrant families applied many types of cheese from the Caucasus in the newly settled Kars region and achieved very fruitful results. Gruyere cheese, one type of the cheese produced was transferred from the Swiss to the Molokans and from the Molokans to the Karapapak. The Molokan cheese was brought to Turkey by the Molokans through migration. 
Quality Gruyere cheese is obtained only from cow's milk. A mixture of sheep and goat milk can be applied for kashar cheese. Morning milk milked in the Kars region in the May-July period gives the best results for Gruyere and kashar production. Immediately after milking, since it is easier to process milk without losing its natural temperature and it maintains its quality, the milk that is milked in the early hours of the morning (around 5:00 am) is taken into the Molokan-made silver cauldrons. The milk cooked in silver cauldrons of about 120 years is often fermented with the şirdan yeast, one of the natural yeasts. The fermented Gruyere cheese is put into large ring-shaped molds. The cheese is compressed and rested to remove the hard water. After a while, the cheese is thrown into the salt pool and is expected to absorb the salt here for a few days (Atış \& Çelikoğlu, 2018: 319). During the interviews conducted in the Kars region, it was stated that Gruyere cheeses produced in the environment, and with the tools and equipment created by the Molokans were better quality than the fabricated products. Molokans also left important marks on the road construction in the Kars region. The $5 \mathrm{~km}$ long Molokan stone road and stone bridge in the Çakmak village are the main examples used still today. These transportation works can be considered as a part of Turkey's cultural tourism.

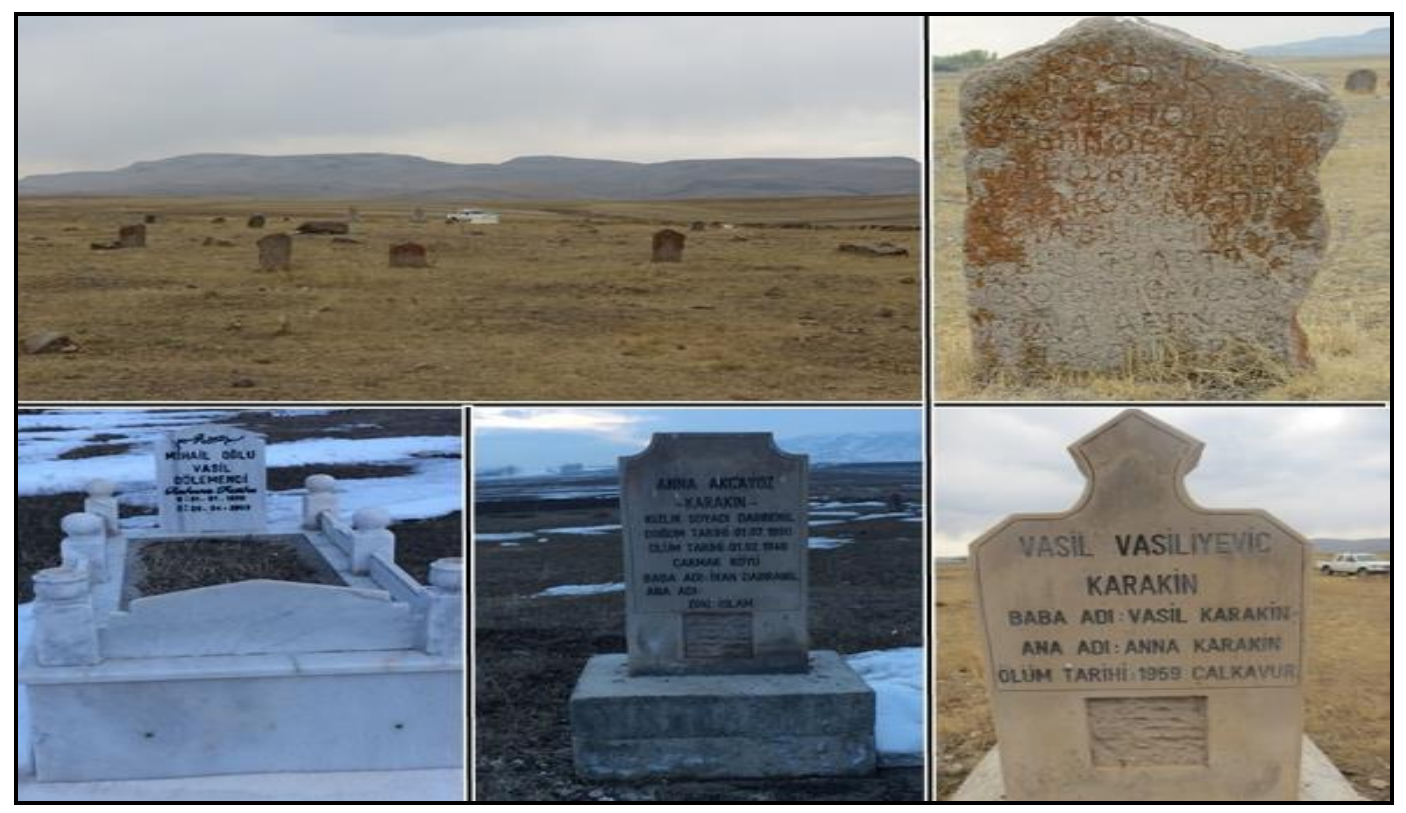

Figure 1o. Samples of Molokan tombs from the Çakmak Village

Cemeteries are important cultural sites that leave a mark on the cultural geographical appearance and reflect the societies' understanding of life, death and faith. Cemeteries are works with social, psychological, artistic, folkloric and ethnic reflections as well as density of settlements, historical background and population characteristics. Traditions and customs of a society are cultural works that give clues about land use, understanding of art, religious laws and landscape architecture. Moreover, the cemeteries are one of the important parts of the cultural landscape which strengthens the bond of the locality with the people and forms a bridge from the past to the future. As can be seen in Figure 10, one of the reflections of the Molokan culture in the Kars region is the cemeteries dating back from past to the present day. Since the Molokans did not adopt the belief of the trinity, no marks of cross 
symbolizing Christianity are found on their tombstones. When the tombstones are examined, it is understood that some Molokans living in the region during the Republican period converted to Islam. The movie "Deli Deli Olma", shot in the Eşmeyazı village of Kars and released in 2009, provides a snapshot of the socio-cultural and economic lives of the Molokans in Kars. The film whose screenplay was written by Hazel Sevim Ünsal, produced by Taygun Aydın and Tolga Aydın, and directed by Murat Saraçoğlu is about the unattainable love of a Molokan youth named Mishka (Tarlk Akan) and a Turkish girl Pabuc (Şerif Sezer). In the movie, Mishka is a miller in the village. The movie featured the migration of Molokans to Kars, their funeral ceremonies, their arts and instruments, Easter celebrations, their relationship with relatives in different localities, and their longing for the relatives in distant lands. In a song that is sung accompanied by a piano in the movie, the Molokans regarded themselves as a society that was dismantled like a couch grass from every place they settled down, but they, in fact, desired to be ivy.

\section{CULTURAL TOURISM POTENTIAL OF THE MOLOKAN CULTURE ELEMENTS}

The Orient Express, which has recently been the center of attention between Ankara and Kars thanks to rail transportation, has brought many domestic and foreign tourists to the province of Kars and enabled the revival of local tourism. The "Ani Archaeological Site", which is located within the borders of Kars and includes the Ani Ruins, was included in the UNESCO World Cultural Heritage List in 2016 (UNESCO, 2020). The Ani Archaeological Site, one of 18 World Cultural Heritage assets of list in question has a significant tourism potential. The Kars Castle, 12 Apostles Church, Fethiye Mosque, historical public baths and stone bridges and examples of Ottoman and Russian civil architecture are among the main tourist attractions of the Kars province.

Furthermore, the Kars province has the touristic sites such as the winter tourism center in the district of Sarıamış and the Allahu Akbar Mountains National Park that hosts the martyrs' cemetery of the troops that froze to death in the Caucasus military operations, the Lake Çıldır located on the Kars-Ardahan border protected as the13th site under the Ramsar Convention of Turkey and the Kuyucuk Lake wetland, which is frequented by important bird species. Furthermore, there is a rich cultural accumulation in terms of gastronomic tourism, especially the rich varieties of cheese and Kars Honey and Kars goose. In addition to these, local produce such as the Kağızman churchkhela of the Kağızman district, fruit pulp, walnut and apricot together with the Kağızman Long Apple which have protected designation of origin with geographic indication registered dated 30.12.2017 and numbered 307 contribute to the diversification of the gastronomic tourism of the province. In recent years, the Boğatepe village has been one of the important destinations proved to make a significant progress in tourism in the province of Kars (especially after 2009). In 2009, an old building from the Molokans in the village was restored with the financial support of 59000 TL from the Serhat Development Agency and an eco-cheese museum was established. The museum in question that is Turkey's first and world's second eco-cheese museum has been one of the places frequently visited by domestic and foreign visitors (NTV, 2019). While establishing our eco-museum, it was aimed to establish the repository of local culture, protect the past cultural accumulation and transfer these to the next generations (Yemek, 2018).

It was thought that eco- museology was an umbrella that protected the local production and local cultures in the face of the developing industry, cultural interaction created by cheese production was emphasized and information obtained through oral history was transformed into products by being supported by the objects and documents. In the museum, what is needed in the production process of cheese from past to present is 
exhibited and at the same time it is ensured that it is preserved and transferred to the future generations. The museum allows the accumulation of knowledge and preservation of the food production chain (Figure 11). Furthermore, exhibiting the materials used by the Molokans also increases the cultural tourism potential of the museum (Anadolu Agency, 2019). Activities such as serving breakfast to tourists by more than 20 of 85 households in the Boğatepe Village, thus allowing them to taste the cheese varieties produced in the village in person, marketing the medicinal and aromatic plants dried in the plant drying workshop established within the "Boğatepe Environment and Life Association" established by the women living in Boğatepe, organizing horseback rides around the village, and visits to the Boğatepe eco-museum, Turkey's first cheese museum constitute an important potential for the rural tourism. It is anticipated that the village of Boğatepe, which is already visited by more than 20000 tourists annually will host more tourists in the future.

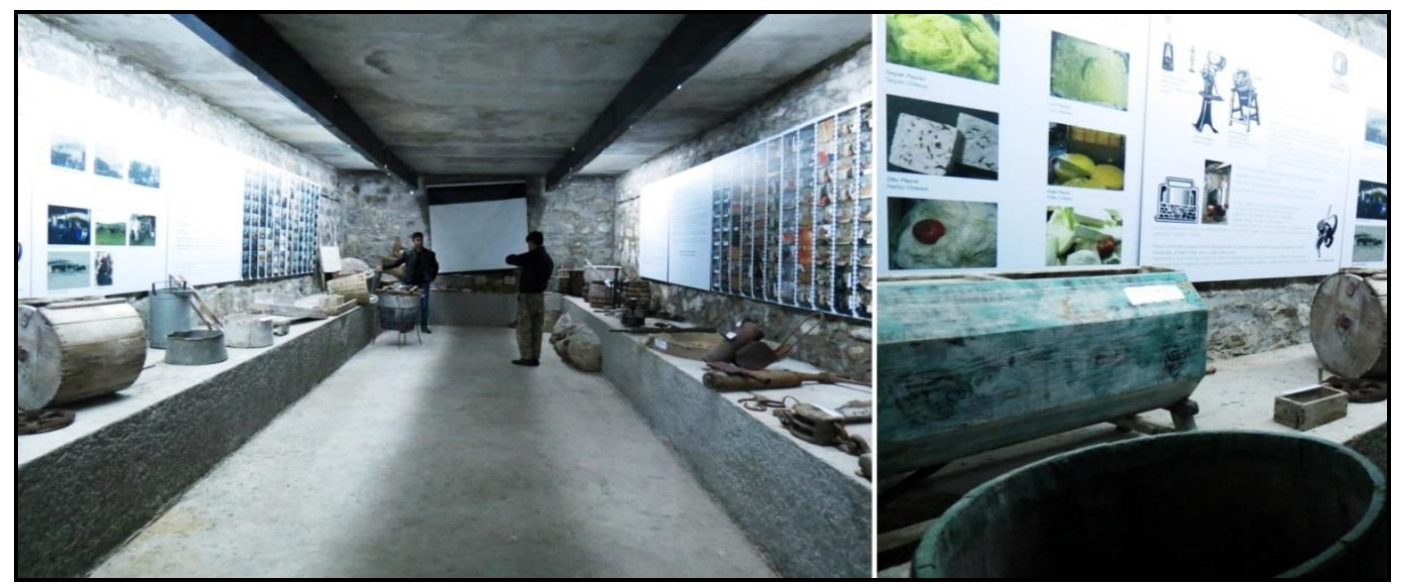

Figure 11. A view from the eco-cheese museum in the Boğatepe village, the first cheese museum in Turkey

Similarly, taking the necessary steps in the name of rural cultural tourism in other villages, especially in the village of Çakmak, and introducing the arrangements including the cultural heritage of communities such as Molokans and Duhobors will begin to benefit to the other villages as well in terms of tourism. As a matter of fact, it has been stated that the communities in question have visited Kars in recent years in order to trace their ancestors. In this context, the fact that Molokans and Duhobors living in different countries of the world visit Kars more frequently and their accommodation here will make an important contribution to the local tourism. For this purpose, it will be beneficial to protect and promote the structures such as houses, stables, mills and Sobranie within the region of Kars and the tools of their own culture that have survived today.

The two peoples, living together and exchanging culture for a long time left peacefully while leaving. In this respect, by meeting some of the Molokans living today, contacting with Molokans and their grandchildren who left our country in the 1960 s and organizing cultural events can be an important tourism resource for Kars and its sorroundings, where Malacans lived at that time (Zaman, 2015:223).

\section{CONCLUSION AND SUGGESTIONS}

Kars and its surroundings remained under Russian rule for more than 40 years as a result of the Ottoman Russian War of 1877-1878 (the '93 War). During this period, in line with the settlement policy of the Russians, approximately 11000 people migrated to the region, including 6500 Molokans and 3000 Dukhobors. On October 30, 1920, annexation 
of the Kars region by the Turkish army led by Kazım Karabekir and the Moscow and Kars treaties in 1921, a significant portion of the Molokans like the other communities who immigrated to the region eventually returned to Russia, and one part of them remained in Turkey. However, in 1962, almost all of the remaining Molokans in the Kars region migrated to Saratov, Russia, which was founded by the Volga River. It is commonly known that the political and social developments that took place during the USSR caused psychological and social unrest among the Molokan community. Moreover, in the Molokan belief system, since it was a sexual taboo to marry even with someone from 5-6 generations earlier, the fact that they did not want to have to marry with very close relatives and that they did not marry with indigenous people caused this migration. Today, it is stated that about 11 Molokans currently continue to live in the Kars region (Gazete Pusula, 2017).

Molokan communities lived in peace and solidarity with the local people about 80 years after they came to the Kars region. During this period, the local people had various socio-cultural, demographic and economic interactions with Molokans. As a result, the Molokans introduced the Molokan and Gruyere cheeses, the Zavod cattle (Molokan cows), Molokan horses, milling, vegetable cultivation, beekeeping and horticulture, the use of Molokan horses in agricultural works, cradle roofed architecture, stables with various strictures and dairy farms and various ornaments to the local culture. Molokans, on the other hand, learned ovine breeding, cheese varieties such as head cheese and knitted cheese specific to the region, and carpet and rug weaving from the local people.

In the Kars Region, architectural elements such as houses, dairy farms, stables, mills, bridges and stone paved roads of the Molokans have survived. In addition to this, the beekeeping and cattle breeding methods used by Molokans are among the elements that continue to exist in the region today. In addition, the Molokan soap factories and their own repair shops are among the cultural elements that continue to exist today.

Consequently, it is clearly observed that the Molokan cultural elements that have existed in the region have an important potential in terms of cultural tourism. These elements can be both transferred to the future generations with an effective approach for protection and contribute to the development and diversification of the local tourism.

In the interviews conducted in the Kars region: It was understood that the ancestors of the Molokans had an interest in the Eastern Anatolian lands where they lived for a period, and that the local people also had a positive opinion of the Molokans. Attracting the Molokans living in various parts of the world to the region in the context of cultural tourism will create a new source of income for the local people and contribute to the sustainability of Molokan cultural elements in the region. In this context, the Molokans who live as diaspora in different parts of the world, especially in California, USA, Canada, Mexico and Australia can be contacted. Web pages with English and Russian language options can be set up to introduce the region to Molokans in detail. In addition, an international congress about Molokans and Duhobors can be organized with the cooperation of Kafkas University and Ardahan University, Molokan and Duhobor scientists, researchers and students living abroad can be encouraged to come to the region and get to know the places where their ancestors or relatives once have lived.

The "Ani Archaeological Site", located within the borders of Kars province and hosting the Ani Ruins, was included in the UNESCO World Cultural Heritage List in 2016. Moreover, the Lake Çlldır located within the borders of Ardahan province and the Kuyucuk Lake wetland, which is the13th site under the Ramsar Convention of Turkey and frequented by important bird species are also located in this region. The Orient Express, which has gained popularity in recent years, adds a new dimension to the local tourism. Furthermore, scientific and artistic activities organized by the Kafkas University also add diversity to local tourism. It is emphasized that there has been deficiency in such areas as 
accommodation, food and beverage facilities and tourism guidance in the face of the increasing tourism demand in the region. In this sense, the Molokan houses can be restored and converted into boutique hotels and restaurants. The Molokan structures and articles can be preserved and exhibited. In addition, it will be beneficial to develop complementary elements such as guidance and transportation services for tourists in order for the region to get its share at the desired level from the international tourism and ensure that the region gets the deserved coverage in the domestic and foreign printed and visual media.

\section{REFERENCES}

Akça, B. \& Kıyanç, S. (2017). Molokans Traces in Anatolia. Journal of Social Sciences and Humanities Researches, 18 (39), 22-43.

Akçayöz, V., (2015). My Mother Sara and the Molokans. Kayhan Typography, Istanbul.

Arat, E., (2019). Russians Taking Refuge in Turkish Soil Throughout History, International Turkish-Russian World Academic Research Congress (14 - 16 Aralık 2018) Proceedings Book, Ankara.

Atış, E., Çelikoğlu, S.. (2018). Contribution of Production of the Traditional Kars Gravyer and Kashar Cheese to Local Economy and Promotion in Boğatepe Village. International Congress on the 75th Anniversary of TGS Proceedings Book, 310-324.

Atasoy, E. (2019). Cultural Geography and Fundamentals of Ethnogeography, Ethnos, Languages, Minorities, Diasporas, Değişim Publications, Istanbul.

Badem, C., (2010). Kars Province under Tsarist Russian Rule, Bir Zamanlar Publications, Istanbul.

Cuche, D., (2013), The Notion of Culture in the Social Sciences , Bağlam Publications, İstanbul.

Denisenko, L. (2009). Russian Imperialism, Russification of the Caucasus and Molokans. Toplumsal Tarih, $187,60-65$.

Doğanay, H., (2011). The Economic Geography of Turkey. Pegem Akademi Publications, Ankara.

Inıkova, S.A. (2007). The Dukhobor and Molokan Ethno-Denominational Groups. Russian Studies in History, $46,(3), 78-96$.

Koday, S. (2005). Livestock in Eastern Anatolia Region, Atatürk Univercity Publications No: 949, Erzurum.

Ortayl, I. ., (1978). Kars in the Era of the Russian Tsardom. Istanbul Univercity Faculty of Letters Journal of History Institute, 9, 343-362.

Özkan, Ö., (2015). Architecture and environment housing front ornaments in Kars, Marmara Univercity Institute of Turkic Studies, Unpublished Master Thesis, Istanbul.

Semyenov I.Y., Karagöz E., (2009). Fading Colors of Exiles' Garden, Su Publications, Istanbul.

Slaveykov. P. (2006). Etnogeografiya, Universitetsko İdatelstvo “Sv. Kliment Ohridski”, Sofya, p. 15.

Somersan, S. (2008). Babil Kulesi'nde Etnilerden Ulus-Devletlere. Doğu-Batı Dergisi, Sayı: 44, Ankara, p. 76.

Sutton, M. Q. \& Anderson, E. N., (2014). Introduction to Cultural Ecology. Altamira Press, Maryland.

Suvari C.Ç. (2013). Molocans, Molokan Belief from Russian Peasant Movements to Present. Ütopya Publications, Ankara.

Tümertekin, E. \& Özgüç, N., (2004). Human Geography, Çantay Bookstore, Istanbul.

Türkdoğan, O. (2005). An Ethnic Group in Kars Molokan Social Structure, IQ Kültür Sanat Publications, Istanbul.

Zaman, N. (2015). Human and Economic Geography of Susuz District, (Unpublished doctoral dissertation thesis). Ataturk Univercity Institute of Social Sciences, Erzurum.

*** Anadolu Agency (2019). https://www.aa.com.tr/tr/kultur-sanat/peynir-muzesine-turistlerden-ilgi-/1430128, Date of Access: 12.01.2020.

*** Baptistru (2020). http://baptistru.info/index.php/, Date of Access: 28.12.2019

*** Gazete Pusula (2017). https://www.gazetepusula.net/2017/11/10/tarihin-emanetleri-rus-asilli-malakanlar/, Date of Access: 10.03.2020.

*** Molokans Wordpress, (2012). https://molokans.wordpress.com/2012/o6/21/history-of-molokans-ingeorgia/, Date of Access:12.01.2020.

*** NTV (2019). https://www.ntv.com.tr/sanat/139-yillik-mandira-peynir-muzesi-oldu,-5FycSARfkyGXCJh XCGWBg, Date of Access: 30.12.2019.

*** Rusian7 (2017). https://russian7.ru/post/molokane-russkie-kotorye-nashli-ubezhi/, Date of Access: 25.12.2019.

*** UNESCO (2020). http://www.unesco.org.tr/Pages/125/122/UNESCO-Dunya-Miras-Listesi, Date of Access: 12.01.2020.

*** Yemek (2018). https://yemek.com/zumran-omur/, Date of Access: 12.01.2020.

*** Yurt Encyclopedia, (1982). Kars Article, Anadolu Publications, Vol.VI, Istanbul.

http://www.molokane.org/, Date of Access: 12.01.2020.

https://www.shuvaeva.info/2018/10/blog-post_17.html, Date of Access: 12.01.2020.

http://molokan.narod.ru/index_long.html, Date of Access: 12.01.2020.

http://molokans.info/bibliography/publications, Date of Access: 12.01.2020.

http://www.blagovest-info.ru/index.php?ss=2\&s=24\&id=17935, Date of Access: 12.01.2020.

Submitted:

02.02.2020
Revised:

17.04.2020
Accepted and published online 27.04.2020 